\title{
ENVIRONMENTAL HEALTH SITUATION OF THREE RURAL COMMUNITIES LIVING IN THE IMMEDIATE VICINITY OF EBRIÉ LAGOON, CÔTE D'IVOIRE
}

\section{Aubin Cyrille TOULE ${ }^{1,2 *}$, Marina KOUSSEMON ${ }^{1}$, Ama Antoinette ADINGRA ${ }^{2}$ et Nadège KOUADIO-N'GBESSO ${ }^{2}$}

${ }^{1}$ Nangui Abrogoua University, Department of Food Science and Technology, 02 BP 801 Abidjan 02, Côte d'Ivoire.

${ }^{2}$ Oceanographic Research Center, BP V18 Abidjan, Côte d'Ivoire.

*Corresponding author : toulenco@gmail.com, toulenco@yahoo.fr, Tel : (+225) 08453887.

\begin{abstract}
In order to update on the state of the environment, a cross-sectional survey was conducted in three rural areas (Layo, Ahua and N'djem) in the front of Ebrié lagoon, to identify risk behaviors threatening the stability of this lagoon and causing some recurrent diseases among the population. This study revealed a lack of systems for drinking water supply as well as wastewater and solid wastes management in the three villages. It was observed that $75.7 \%$ of the households used boreholes and $24.3 \%$ used wells as their main source of drinking water. Meanwhile $37.9 \%$ of households practiced open defecation. Traditional showers were used by $70.4 \%$ of households and $29.6 \%$ used the lagoon for their shower. The majority households $(94.9 \%)$ disposed their wastewater into the environment. For the storage of solid wastes, $61.2 \%$ of households did so in nature and $38.8 \%$ in the lagoon. About $84.3 \%$ of households were bathing in the Ebrié lagoon while $75.9 \%$ defecating in it. Furthermore, 36.8\% of the surveyed households used lagoon waters for many activities (bathing, washing clothes and dishes), while 59.4\% considered that the lagoon was polluted. Up to $60.6 \%$ of households linked the pollution of lagoon to the occurrence of diseases. The most recurring diseases were dermatoses and water-borne illness like malaria, diarrhea and typhoid fever.

Preventive measures such as the construction of adequate sanitation facilities and health education campaigns should be taken by the authorities to prevent the proliferation of these infectious diseases in the rural population in the future.
\end{abstract}

Keywords : Survey, households, recurrent diseases, pollution, Ebrié lagoon.

(C) The Authors. This work is licensed under the Creative Commons Attribution 4.0 International Licence. 


\section{RESUME}

Afin de faire l'état des lieux de la situation environnementale, une enquête transversale a été menée dans trois zones rurales (Layo, Ahua et N'djem) en bordure la lagune Ebrié afin d'identifier les comportements à risque menaçant la stabilité cette lagune et provoquant certaines maladies récurrentes parmi la population. Cette étude a révélé un manque de systèmes d'approvisionnement en eau potable et de gestion des eaux usées et des déchets solides dans les trois villages. Il a été observé que, 75,7\% des ménages utilisent des forages et $24,3 \%$ des puits comme principale source d'eau potable. Pendant ce temps, $37,9 \%$ des ménages pratiquent la défécation à l'air libre. Les douches traditionnelles sont utilisées par 70,4\% des ménages et 29,6\% utilisent la lagune pour leur douche. La majorité des ménages (94,9\%) évacuent leurs eaux usées dans la nature. Pour le stockage des déchets solides, 61,2\% des ménages le font dans la nature et 38,8\% dans la lagune. Environ 84,3\% des ménages se baignent dans la lagune Ebrié alors que $75,9 \%$ y défèquent. De plus, 36,8\% des ménages enquêtés utilisent les eaux lagunaires pour de nombreuses activités (baignade, lessive et vaisselle), alors que 59,4\% estiment que la lagune est polluée. Jusqu'à $60,6 \%$ des ménages ont établi un lien entre la pollution de la lagune et la survenue de maladies. Les maladies les plus répandues sont les dermatoses et les maladies d'origine hydrique telles que le paludisme, la diarrhée et la fièvre typhoïde.

Des mesures préventives telles, la construction des installations sanitaires adéquates et des campagnes d'éducation sanitaire devraient être prises par les autorités pour éviter dans l'avenir, la prolifération de ces maladies infectieuses au sein de la population rurale.

Mots clés: Enquête, ménages, maladies récurrentes, pollution, lagune Ebrié. 


\section{INTRODUCTION}

Urban water sources are being polluted by inadequate sanitation, poor wastewater management and human activities. This is the case of the Ebrié lagoon which receives all the untreated wastes of the population of Abidjan, the economic capital, and in some peri urban and peripheral cities and villages (Dongo $\mathbb{e}$ al., 2010). This lagoon received $40000 \mathrm{~m}^{3}$ of domestic and industrial wastewater from the city of Abidjan each day (Koné et al., 2007). The inadequacy of urban and rural sanitation technologies for waste management has environmental and human health consequences (Haryanto et Sutomo, 2012). The pollution of the lagoon could have both health and economic consequences due to the many uses of water and fishery products (Meays et al., 2004). Sewage disposal affect people's immediate environment and leads to water-borne illnesses. Poor water quality, poor hygiene and insufficient sanitation are the causes of water-borne diseases, particularly water-borne diseases (Ledeur, 2004; Kientga, 2008). Every year, nearly 8 million people, half of whom are children, die from diseases due to water quality, lack of water, poor hygiene or sanitation (Camdessus et al., 2004).
Surface water plays an important role in the distribution of vectors and spatial and temporal transmission of disease (Poda, 2007).

The objective of this study was to evaluate the environmental health situation of the populations living in sectors IV and V of the Ebrié lagoon and to identify the health risk factors related to the living conditions of these populations on the stability of the lagoon environment.

\section{MATERIAL AND METHODS}

\section{Study area}

This study was carried in three villages (Layo, Ahua and N'djem). The choice of these localities was based on their location in sectors IV and V of the Ebrié lagoon. In these two sectors, massive fish deaths have occurred in 2013. This has resulted in the closure of numerous fish farms in this area. Layo is located in the department of Dabou, $45 \mathrm{~km}$ west of Abidjan on the axis Abidjan-Dabou. Ahua and N'djem are located in the department of Jacqueville. Ahua is about 57 $\mathrm{km}$ from Abidjan and N'djem, about $33 \mathrm{~km}$ on the axis Abidjan-Jacqueville.

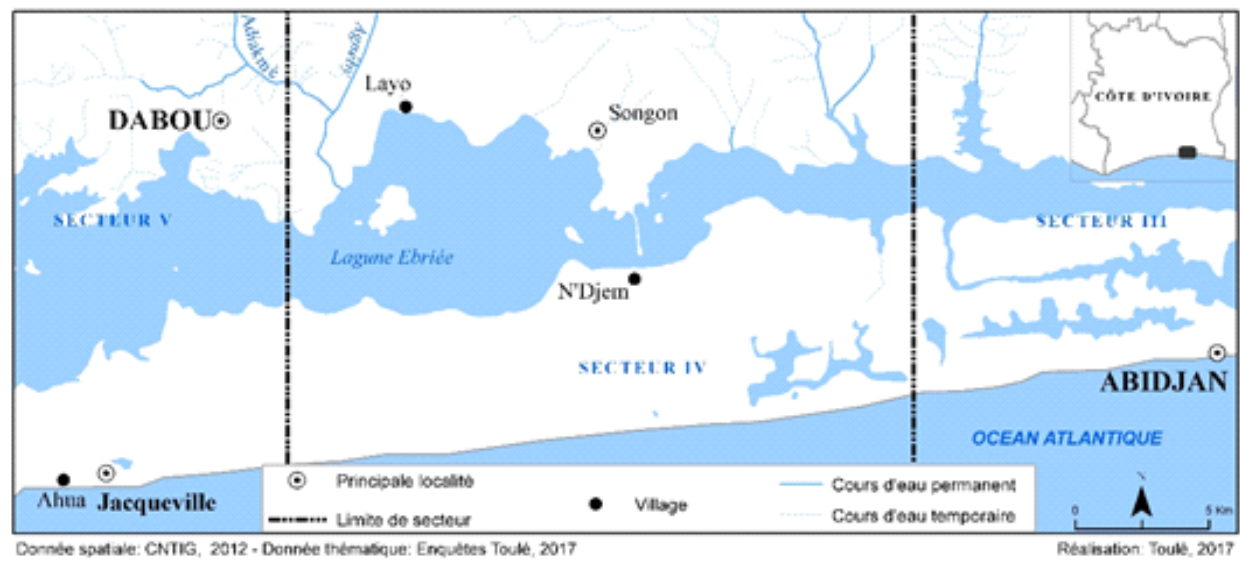

Figure 1: Study Area

\section{HOUSEHOLD SURVEY}

We selected the communities of Layo, Ahua and N'djem as the areas of interest. The target for sampling were the households. The community of Layo consists of 96 households, those of Ahua is 78 and those of N'djem, 533. The survey was conducted in March 2015 in 212 households, of which 29 were in Layo, 23 in Ahua and 160 in N'djem, which corresponded to about $30 \%$ of households in each village. Random sampling was used to select households (MSLS, 2012), because random sampling gives to each household an equal chance to be selected. 
The research employed the use of structured questionnaires. The questionnaires were distributed personally in each of the selected households in the community of the three villages. The questionnaire consisted of a set of questions that were presented to the head of the household or his representative for answers. The questionnaire was divided into three sections. In the first section, respondents were asked about their demographic characteristics such as the composition of the household, the employment status, the level of education. In the second section, the respondents were asked about the living conditions such as the water sources, the type of latrine used, wastewater and solid waste disposal practice. In the third section, the respondents were asked for their diet habits, the source of fishery products, risk behaviors, their perception of the lagoon pollution and its consequences on health, their knowledge and perception about disease and health.

\section{STATISCAL ANALYSIS}

The data were analyzed using the Epi Info 3.5.1 software to assess the link between water pollution and human activities.

\section{RESULTS}

The characteristics of households surveyed are presented in Table I. It can be seen that $94 \%$ of households were headed by men. The heads of the households were self-employed; they did activities such as fishing (43.5\%) and selling fishery products $(78.5 \%)$. In terms of educational background, the majority of selected households in the three villages (56.5\%) were illiterates. Most people dropped out of primary and secondary schools of the lack of financial resources.

Table II shows the sources of drinking supply and the sanitary facilities. For drinking water supply, most households surveyed $(75.7 \%)$ used boreholes while $24.3 \%$ used hand dug wells. The main type of latrine used by the households surveyed was the open defecation in the bush $(37.9 \%)$, followed by defecation on the borders of the lagoon $(31.5 \%)$ and overhung latrines (22.5\%). Most households (70.4\%) used traditional bathrooms against $29.6 \%$ who bathed directly in the lagoon. Solid wastes and wastewater were dumped directly on the street, the open fields and in the lagoon by $94.9 \%$ and $61.2 \%$ of the households surveyed. The type of fishery products consumed by surveyed households in the three villages are presented in Table III. Fish were the most widely consumed fishery products in households (100\%), followed by crabs $(27.8 \%)$, shrimps $(8.3 \%)$ and crayfish $(1.6 \%)$. A total of $98.2 \%$ of these fishery products came from the Ebrié lagoon.

Table IV present the risk behaviors of surveyed households in the villages. About $84.3 \%$ of surveyed households bathed, defecated $(75.9 \%)$ and $62.5 \%$ disposed of their wastes in the Ebrié lagoon. The waters of the lagoon were also used for domestic tasks, with a proportion of $33.5 \%$ for laundry and $9.5 \%$ for dishes. The status of pollution of the Ebrié lagoon and the recurrent diseases according to the opinions of the households are recorded in Table V. Half households surveyed (59.4\%) has affirmed that the Ebrié lagoon was polluted. Changes in color, foul odors and solid waste were the most commonly reported signs of pollution by households. Pollution sources were most attributed to runoff water, domestic wastes, open defecations, agricultural wastes, and industrial wastes. $60.6 \%$ of households linked the pollution of the lagoon to the occurrence of disease cases. Table V shows that malaria was the most common recurrent disease reported by all households $(77.9 \%)$ followed by cases of dermatosis $(28.7 \%)$, diarrhea (20.2\%) and typhoid fever (12.4\%). About $13.2 \%$ of cases of diarrhea were recorded in all the households surveyed. 
Table I : Demographic characteristics of respondents in households

\begin{tabular}{|c|c|c|c|c|}
\hline \multirow[b]{3}{*}{ Characteristics } & \multicolumn{3}{|c|}{ Distribution $(\%)$} & \multirow[b]{3}{*}{ Means } \\
\hline & \multicolumn{3}{|c|}{ Localities } & \\
\hline & Layo $(n=29)$ & Ahua $(n=23)$ & N'djem $(n=160)$ & \\
\hline \multicolumn{5}{|l|}{ Sex of head of household } \\
\hline Female & 0 & 8,7 & 9,4 & $6 \pm 5,2$ \\
\hline Male & 100 & 91,3 & 90,6 & $94 \pm 5,2$ \\
\hline \multicolumn{5}{|c|}{ Educational status of head of household } \\
\hline No formal education & 51,7 & 69,6 & 48,2 & $56,5 \pm 11,5$ \\
\hline Primary school & 20,7 & 17,4 & 30,6 & $22,9 \pm 6,9$ \\
\hline Secondary school & 24,1 & 13 & 18,1 & $18,4 \pm 5,6$ \\
\hline High school & 3,5 & 0 & 3,1 & $2,2 \pm 1,9$ \\
\hline \multicolumn{5}{|l|}{ Main source of income } \\
\hline Agriculture & 6,9 & 4,3 & 12,5 & $7,9 \pm 4,2$ \\
\hline Fishing / sale of fishing products & 75,9 & 87 & 72,5 & $78,5 \pm 7,6$ \\
\hline Breeding & 0 & 8,7 & 1,9 & $3,5 \pm 4,6$ \\
\hline Commerce & 10,3 & 0 & 9,4 & $6,6 \pm 5,7$ \\
\hline Salaried / day laborer & 6,9 & 0 & 3,7 & $3,5 \pm 3,5$ \\
\hline
\end{tabular}

Table II : Drinking water supply and sanitary facilities used by households surveyed

\begin{tabular}{|c|c|c|c|c|}
\hline \multirow[b]{3}{*}{ Characteristics } & \multicolumn{3}{|c|}{ Distribution (\%) } & \multirow[b]{3}{*}{ Means } \\
\hline & \multicolumn{3}{|c|}{ Localities } & \\
\hline & Layo $(n=29)$ & Ahua $(\mathrm{n}=23)$ & N'djem $(n=160)$ & \\
\hline \multicolumn{5}{|c|}{ Main source of drinking water supply } \\
\hline Communal faucet & 0 & 0 & 0 & 0 \\
\hline Borehole & 100 & 100 & 27,5 & $75,8 \pm 41,9$ \\
\hline Well & 0 & 0 & 72,5 & $24,2 \pm 41,9$ \\
\hline Surface water & 0 & 0 & 0 & 0 \\
\hline \multicolumn{5}{|l|}{ Main type of latrine used } \\
\hline Modern latrine & 0 & 0 & 0 & 0 \\
\hline Traditional latrine & 6,9 & 0 & 17,5 & $8,1 \pm 8,8$ \\
\hline Overhung Latrine & 0 & 0 & 67,5 & $22,5 \pm 39$ \\
\hline Open defecation & 17,2 & 82,6 & 13,8 & $37,9 \pm 38,8$ \\
\hline Borders of the lagoon & 75,9 & 17,4 & 1,2 & $31,5 \pm 39,3$ \\
\hline \multicolumn{5}{|c|}{ Main type of bathroom used } \\
\hline Modern bathroom & 0 & 0 & 0 & 0 \\
\hline Traditional bathroom & 13,8 & 100 & 97,5 & $70,4 \pm 49,1$ \\
\hline Lagoon & 86,2 & 0 & 2,5 & $29,6 \pm 49,1$ \\
\hline \multicolumn{5}{|c|}{ Wastewater management } \\
\hline Canal & 0 & 0 & 0 & 0 \\
\hline Septic tank & 3,4 & 0 & 6,9 & $3,4 \pm 3,5$ \\
\hline Street & 96,6 & 95,7 & 92,5 & $94,9 \pm 2,2$ \\
\hline
\end{tabular}


REVUE DE L'ACADEMIE DES SCIENCES DU CAMEROUN Vol. 14 No. 1 (2017)

Table III : Consumption, mode of acquisition and origin of fishery products

\begin{tabular}{|c|c|c|c|c|}
\hline \multirow[b]{3}{*}{ Characteristics } & \multicolumn{3}{|c|}{ Distribution $(\%)$} & \multirow[b]{3}{*}{ Means } \\
\hline & \multicolumn{3}{|c|}{ Localities } & \\
\hline & Layo $(\mathrm{n}=29)$ & Ahua $(\mathrm{n}=23)$ & N'djem $(n=160)$ & \\
\hline \multicolumn{5}{|c|}{ Most consumed fishery products } \\
\hline Fish & 100 & 100 & 100 & 100 \\
\hline Crab & 13,8 & 52,2 & 17,5 & $27,8 \pm 21,2$ \\
\hline Shrimp & 0 & 21,7 & 3,1 & $8,3 \pm 11,7$ \\
\hline Crayfish & 0 & 4,3 & 0,6 & $1,6 \pm 2,3$ \\
\hline \multicolumn{5}{|c|}{ Mode of acquisition of fishery products } \\
\hline Fishing & 93,1 & 100 & 85,6 & $92,9 \pm 7,2$ \\
\hline Buy & 6,9 & 0 & 14,4 & $7,1 \pm 7,2$ \\
\hline \multicolumn{5}{|c|}{ Origin of fishery products } \\
\hline Ebrié lagoon & 100 & 100 & 94,7 & $98,2 \pm 3,1$ \\
\hline Other & 0 & 0 & 5,3 & $1,8 \pm 3,1$ \\
\hline
\end{tabular}

Table IV : Risk behaviors of surveyed households in the three villages.

\begin{tabular}{lllll}
\hline & \multicolumn{3}{c}{ Distribution (\%) } \\
\cline { 2 - 4 } Risk Behaviors & \multicolumn{3}{c}{ Localities } \\
\cline { 2 - 4 } & Layo $(\mathrm{n}=29)$ & Ahua $(\mathrm{n}=23)$ & N'djem $(\mathrm{n}=160)$ & Means \\
\hline Bathing & 96,5 & 91,3 & 65 & $84,3 \pm 16,9$ \\
Defecation & 86,2 & 69,6 & 71,9 & $70,8 \pm 1,6$ \\
Garbage throwing & 62,1 & 60,9 & 64,4 & $62,5 \pm 1,8$ \\
Cooking & 0 & 0 & 0 & 0 \\
Washing Dishes & 10,3 & 0 & 18,1 & $9,5 \pm 9,1$ \\
Laundry & 41,4 & 21,7 & 37,5 & $33,5 \pm 10,4$ \\
\hline
\end{tabular}


Table V : Opinions on the pollution status of Ebrié lagoon waters and recurrent diseases cases

\begin{tabular}{|c|c|c|c|c|}
\hline \multirow[b]{3}{*}{ Opinions } & \multicolumn{3}{|c|}{ Percentages $(\%)$} & \multirow[b]{3}{*}{ Means } \\
\hline & \multicolumn{3}{|c|}{ Localities } & \\
\hline & Layo $(\mathrm{n}=29)$ & Ahua $(n=23)$ & N'djem $(n=160)$ & \\
\hline \multicolumn{5}{|c|}{ Nature of the Ebrié lagoon } \\
\hline Polluted & 65,5 & 47,8 & 65 & $59,4 \pm 10,1$ \\
\hline Unpolluted & 31 & 34,8 & 17,5 & $27,8 \pm 9,1$ \\
\hline No idea & 3,4 & 17,4 & 17,5 & $12,8 \pm 8,1$ \\
\hline \multicolumn{5}{|l|}{ Signs of pollution } \\
\hline Odor & 31 & 17,4 & 32,5 & $27 \pm 8,3$ \\
\hline Color & 55,2 & 30,4 & 27,5 & $37,7 \pm 15,2$ \\
\hline Solid waste & 17,2 & 13 & 43,1 & $24,4 \pm 16,2$ \\
\hline Sludge & 0 & 13 & 5 & $6 \pm 6,6$ \\
\hline Lack of fish & 6,9 & 4,3 & 13,1 & $8,1 \pm 4,5$ \\
\hline \multicolumn{5}{|l|}{ Sources of pollution } \\
\hline Domestic waste & 44,8 & 34,8 & 55,6 & $45,1 \pm 10,4$ \\
\hline Industrial waste & 13,8 & 17,4 & 14,6 & $15,3 \pm 1,4$ \\
\hline Agricultural Waste & 48,3 & 13 & 18,1 & $26,5 \pm 19,1$ \\
\hline Anarchic defecations & 37,9 & 21,7 & 44,4 & $34,7 \pm 11,7$ \\
\hline Runoff water & 41,3 & 47,8 & 50 & $46,4 \pm 4,5$ \\
\hline Periodic & 0 & 17,4 & 4,4 & $7,3 \pm 9$ \\
\hline \multicolumn{5}{|c|}{ Link between water pollution and diseases } \\
\hline Link & 69 & 52,2 & 60,6 & $60,6 \pm 8,4$ \\
\hline No link & 20,7 & 34,8 & 25,6 & $27 \pm 7,2$ \\
\hline No idea & 10,3 & 13 & 13,8 & $12,4 \pm 1,8$ \\
\hline \multicolumn{5}{|l|}{ Recurrent diseases } \\
\hline Malaria & 82,8 & 73,9 & 76,9 & $77,9 \pm 4,5$ \\
\hline Typhoid fever & 10,3 & 8,7 & 18,1 & $12,4 \pm 5$ \\
\hline Diarrheal diseases & 20,7 & 13 & 26,9 & $20,2 \pm 7$ \\
\hline Dermatosis & 34,5 & 21,7 & 30 & $28,7 \pm 6,5$ \\
\hline diarrhea & 13,8 & 8,4 & 17,5 & $13,2 \pm 3,2$ \\
\hline
\end{tabular}

Means per locality may be greater than 100\% because each household may incriminate more than one sign, one source of pollution or one disease.

\section{DISCUSSION}

The main source of income for most surveyed households was fishing. In general, these waterfront communities were traditionally fishermen (Diaby et al., 2012). Fishing activity, often informal, contribute to the food security and create jobs for the rural population. According to Adingra and Kouassi (2011), the lagoon fishery, contribute to the food security of the families of the fishermen, and through the marketing of fishery products, increase the financial income of these families. The fishery products (fish, crabs, shrimps, crayfish) consumed by all the households surveyed come mostly from the Ebrié lagoon. According to Koffi (2009), lagoon fisheries resources play an important role in the diet of communities living in front of the lagoon. However, these resources could constitute 
a public health risk if contaminated by the pathogenic micro-organisms that proliferate in this lagoon (Koffi-Nevry et al., 2008).

In this study, none of the surveyed households in the villages was connected to the national water distribution network. In Layo and Ahua, households used only borehole as a source of drinking water. In N'djem, the majority of the households used hand dug wells. These water sources were considered to yield freshwater from the ground (Rowan, 2008). This was supported by Bogaard et al. (2008) that groundwater was the largest storage of freshwater. The failure by the municipality to extend water and sanitation services to villagers put people at risk. The villages are forced to use open sources water from rivers, hand dug wells and boreholes which often have serious consequences to health and hygiene (Maoudombaye et al. 2015). However, the wells, because of their proximity to the polluted Ebrié lagoon could be directly contaminated by bacteria, virus, protozoa, nematodes, etc... as indicated by Kifuani (2004). These unprotected wells could also be contaminated by the water collection vessels such as buckets and ropes, that usually lie around the wells. A study on the assessment of the hygienic quality of well and source water in Morocco undertaken by El Ouali et al. (2014) showed a poor bacteriological quality of well water due to the presence of fecal coliforms, faecal streptococci) at high levels.

None of the households surveyed had modern latrines and bathrooms. In Layo, most households commonly bathed and defecated directly in the Ebrié lagoon. In Ahua, households practiced open defecation in the bush and bathed in traditional bathrooms. In N'djem, the overhung latrines and the traditional bathrooms were commonly used by households and all the wastewater generated were directly drained into the lagoon. In General, coastal and waterfront communities such these living on the border of the Ebrié lagoon, are faced with a wide range of problems caused by their location and environment. Sanitation is a predominant concern. Sanitation facilities are absent and direct defecation into the surface water has been the traditional practice. The overhung latrine is commonly used. Inadequate sanitation has negative effects on health (e.g. waterborne diseases: diarrheal diseases, intestinal infections, polio, typhoid, cholera, etc), economy (e.g. poverty, illness, illiteracy and lost income inclusive of GDP and GNP) and environment (e.g. dispersed and diffuse pollution of water sources resulting in the water and faecal disease cycle for communities with untreated water supplies) (DWAF, 1996; 2001). It also leads to social and psychological problems such as loss of privacy and dignity and exposure and increased risk to personal safety. In worse cases, the Ebrié lagoon over which such latrines are built, the water is used for domestic and personal washing, thereby increasing the risk of contracting diseases (Koffi, 2009). This behavior was observed in Layo and N'djem, where households used the lagoon water for washing dishes and laundry, while in Ahua this water was used only for laundry. It is likely that this situation observed in these villages could be due to the absence of public drinking water services, but it should also be pointed out that this could be due to the lack of awareness of these populations about the health risks associated with their behavior.

The solid and liquid wastes generated in the study area are disposed indiscriminately, as most of the inhabitants either dispose their wastes in open fields, at the side of the road, on the border of the lagoon and in the lagoon as indicated by Sackou et al. (2006) and Koffi-Nevry et al. (2008). These practices pose a risk to public health. Improper waste disposal by households also created a favorable environment for disease- 
carrying pests such as rodents, flies, and cockroaches. These pests not only transmit disease directly but also expose inhabitants to allergens as indicated by Rauh et al. (2002).

Concerning the knowledge and perception about the pollution of the lagoon, the majority of the households surveyed found that the Ebrié lagoon was polluted. According to them, the obvious signs of this pollution were water color change, foul-smelling odors and the presence of solid waste. The obvious causes are runoff water, domestic waste, uncontrolled defecation, agricultural waste and industrial waste. They also mainly linked the pollution of the lagoon to the occurrence of disease cases. As a result, four diseases such as malaria, dermatosis, diarrhea and typhoid fever, were identified in this study as the most recurring diseases in all households. These diseases are important causes of morbidity, and sometimes generate significant disabilities as well as stigmatization of affected populations, perpetuating poverty (Freeman et al., 2013). In under developed country such as Cote d'Ivoire it is difficult to quantify morbidity and mortality related to unsafe and inadequate sanitation because of lack of an effective monitoring and surveillance system and country-wide baseline survey. Malaria was the recurring disease most often incriminated by the households. Similar observations were made by Sy et al. (2011) in their study on health and environmental vulnerability in disadvantaged neighborhoods in Mauritania. Malaria is a major cause of morbidity and mortality in Côte d'Ivoire, where it is endemic (Koné, 2008).

The diarrhea cases reported in this study were higher than those published by the Ministry of Health and AIDS in 2011, which were 7.6\% and $6.7 \%$ respectively in the departments of Dabou and Jacqueville. This difference can be explained by the fact that the statistics only take into account the data collected from the public health centers, whereas some patients do not attend them and they do self-medication or use traditional medicine. Diarrheal diseases are considered an important public health problem because of their frequency and high rate of infant mortality attributable to them (Wierzba et al., 2006). The National Institute of Statistic (INS) reported 18\% of cases of diarrhea in children under 5 years of age in the 2013 Multiple Indicator Cluster survey (MICS).

\section{CONCLUSION}

This study showed that there is strong anthropogenic pressure on the Ebrié lagoon. The lack of adequate sanitary facilities and proper waste disposal system in the study area forced communities living in front of the Ebrié lagoon to dumped all their wastes into the lagoon and open fields indiscriminately. Dumping of wastes into the lagoon contaminate the water making it unsafe for human consumption while dumping in open fields leave the environment very untidy. Health education would therefore be necessary to prevent the health risks associated with these behaviors and to avoid possible epidemics.

\section{RECOMMENDATIONS}

In view of potential risks of the environment of rural areas bordering the Ebrié lagoon on public health, it seems important for the authorities to invest in the construction of adequate sanitation facilities in these areas, to carry out sensitization campaigns on the hazards associated with risky behavior towards populations in order to encourage them to good hygiene practices.

\section{ACKNOWLEDGEMENTS}

We thank the local chiefs of the three villages and all the households surveyed for their collaboration and availability without which the results of this survey could not have been obtained. 


\section{REFERENCES}

Adingra A. A. et Kouassi A. M. (2011). Pollution en lagune Ebrié et ses impacts sur l'environnement et les populations riveraines. $\mathrm{F}$. Tech \& Doc Vulg, 48-53.

Bogaard, T., Mkhandi, S., Parida, B. et Winsemuis, H . (2008). Water Resources Assessment in Sub-Saharan Africa: Prediction in Ungauged and Data Scarce Basins. [online]. Retrieved from htt://www. Cap.net.org/sites/ capnet.org/files/WaterNet\%20Pub\%20 Course\% 20 Reader_0.pdf [2011, June. 13].

Camdessus M., Badré B., Chéret I. \& TénièreBuchot P. F. 2004. Eau. Edition Robert Laffont. Paris. Jeune Afrique Econamies 360 : 40-46.

Diaby M., N’Da K. et Konan K. S. (2012). La pêche des poissons Muglidaedans la lagune de Grand-lahou (Côte d'ivoire) : analyse de l'organisation de la pêche, des captures et de l'effort de pêche. Tropialtura, 30 (3) : 173-179.

Dongo K., Zurbrügg C., Cissé G., Obrist B., Tanner M. et Biémi J. (2010). Analysing environmental risks and perceptions of risks to assess health and well-being in poor areas of Abidjan. WorddAcad Sa. Eng Technd, 37 : 961967.

DWAF. (1996). National Sanitation Policy. National Sanitation Task Team. Republic of South Africa. Pretoria: Government Printers.

DWAF. (2001). White Paper on Basic Household Sanitation. Pretoria : Government Printers.

El Ouali Lalami A., EL-Akhal F., Berrada S., Bennani L., Raiss N. et Maniar S. 2014. Evaluation de la qualité hygiénique des eaux de puits et de sources par l'utilisation d'une analyse en composantes principales (ACP) : Une étude de cas de la région de Fès (MAROC). J. Mater. Enuiron Sa., 5 (S1) : 2333-2344.

Freeman M. C., Ogden S., Jacobson J., Abbott D., Addiss D. G., Amnie A. G., et al. (2013). Integration of Water, Sanitation, and Hygiene for the Prevention and Control of Neglected Tropical Diseases : A Rationale for Inter-Sectoral Collaboration. PLOS Neg. Trop Dis, 7 (9) : 1-9. INS. (2013). Enquête Démographique et de Santé et à Indicateurs Multiples (EDS-MICS) 20112012. Rapport final, Côte d'Ivoire, p. 561.

Haryanto B. et Sutomo S. (2012). Improving access to adequate water and basic sanitation services in Indonesia. Rev. Environ Health, 27 : 159-162.

Kientga S. (2008). Contribution du SIG à l'analyse des leisn déchets-santé en milieu urbain dans les pays en développement. Cas des deux secteurs de la ville de Ouagadougou, Bukina Faso. Thèse de Doctorat, Ecole polytechnique fédérale de Lausanne, Suisse, p. 241.

Kifuani K. M. (2004). Etude de la qualité des eaux, des effluents d'eaux usées domestiques, Mémoire de DES, facultés des sciences, UNIKIN, République démocratique du Congo, p. 65.

Koffi B. E. (2009). L'environnement et la santé des populations riveraines de la lagune Ebrié. Le Joumal des Saienes Sociales $6: 103-116$.

Koffi-Nevry R., Manizan P. N., Wognin S. A., Koussemon M., Koffi S. O., Kablan T. et Kakou C. (2008). Caractérisation de la Répartition Spatio-Temporelle des Bactéries à L'interface Eau-Sédiment D’une Lagune Tropicale : Cas de la Baie du Banco, Abidjan, Côte d'Ivoire. European Jaumal of Saientific Reserch 21 : 164-174. 
Koné B., Doumbia M. et Adji F. X. (2007). Approche écosystémique à la gestion des maladies diarrhéiques en milieu périurbain : cas d'un village lagunaire dans la commune de Yopougon (Abidjan, Côte d'Ivoire). Projet de recherche Centre Suisse de Recherches Scientifiques en Côte d'Ivoire, rapport final, p. 81.

Koné B. (2008). Pollution lagunaire, risques sanitaires et environnementaux dans trois villages périurbains de la commune de Yopougon (Abidjan, Côte d'Ivoire). Thèse unique de l'Université d'Abobo-Adjamé, Abidjan Côte d'Ivoire, p. 285.

Ledeur S. (2004). Utilisation d'un système d'information géographique comme outil de compréhension des épidémies d'origines hydrique et comme outil d'aide à la décision : étude dans un contexte urbain (Ouagadougou, Burkina Faso). Mémoire d’ingénieur du Génie sanitaire, Ecole nationale de santé publique. Rennes, France, p. 65.

Maoudombaye T., Ndoutamia G., Seid Ali M. et Ngakou A. (2015). Etude comparative de la qualité physico-chimique des eaux de puits, de forages et de rivières consommées dans les bassins pétroliers de Doba au Tchad. Larhyss Jaumal, 24 : 193-208.

Meays C. L., Broersma K., Nordin R. et Mazumder A. (2004). Source tracking fecal bacteria in water : a critical review of current methods. J. Enmiron Manag, $73:$ 71-79.

MSLS. (2012). Enquêtes nutritionnelles basées sur la méthodologie SMART. Rapport final. République de Côte d'Ivoire. p. 53.

Poda J. N. (2007). Les maladies liées à l'eau dans le bassin de la Volta : état des lieux et perspectives. Volta Basin Focal Project Report No 4. IRD,
Montpellier. France, and CPWF, Colombo, Sri Lanka, p. 87.

Rauh, V. A., Chew, G. R. et Garfinkel, R. S. (2002). Deteriorated housing contributes to high cockroach allergen levels in inner-city households. Enviranmental Health Pespeetives 110 (S2) : 323 327.

Rowan M. (2008). An assessment of the water and sanitation problems in New forest, Bushbuckridge, local municipality, South Africa. Master degree in the disaster management training and education center for Africa at the University of the free stale, South Africa, p. 92.

Sackou K. J., Claon J. S., Oga A. S., Aguessi K. T., Lorougnon D., Diby Y. et Kouadio K. L. (2006). Qualité sanitaire des laitues cultivées à Abidjan. Miadbid. hyg Alim, 18 (52) : 48-50.

Sy I., Koita M., Traoré D., Keita M., Lo B., Tanner M. et Cissé G. (2011). Vulnérabilité sanitaire et environnementale dans les quartiers défavorisés de Nouakchott (Mauritanie) : analyse des conditions d'émergence et de développement de maladies en milieu urbain sahélien. Vetigo, 11 (2) : 1-17.

Wierzba T. F., Abdel-Messih I. A., Abu-Elyazeed R. E. M. O., Putnam S. D., Kamal K. A., Rozmajzl P. A. T. R., Ahmed S. F., Fatah A. B. D. E., Zabedy K. H. A. L., Shaheen H. I., Sanders J. O. H. N. et Frenck R. O. B. E. (2006). Clinicbased surveillance for bacterial and rotavirusassociated diarrhea in egyptian children. Ammican Jaumal of Tropical Mediaine and Hygiene, 74 : 148 153.

Received: 12/05/2017

Accepted: 13/09/2017 